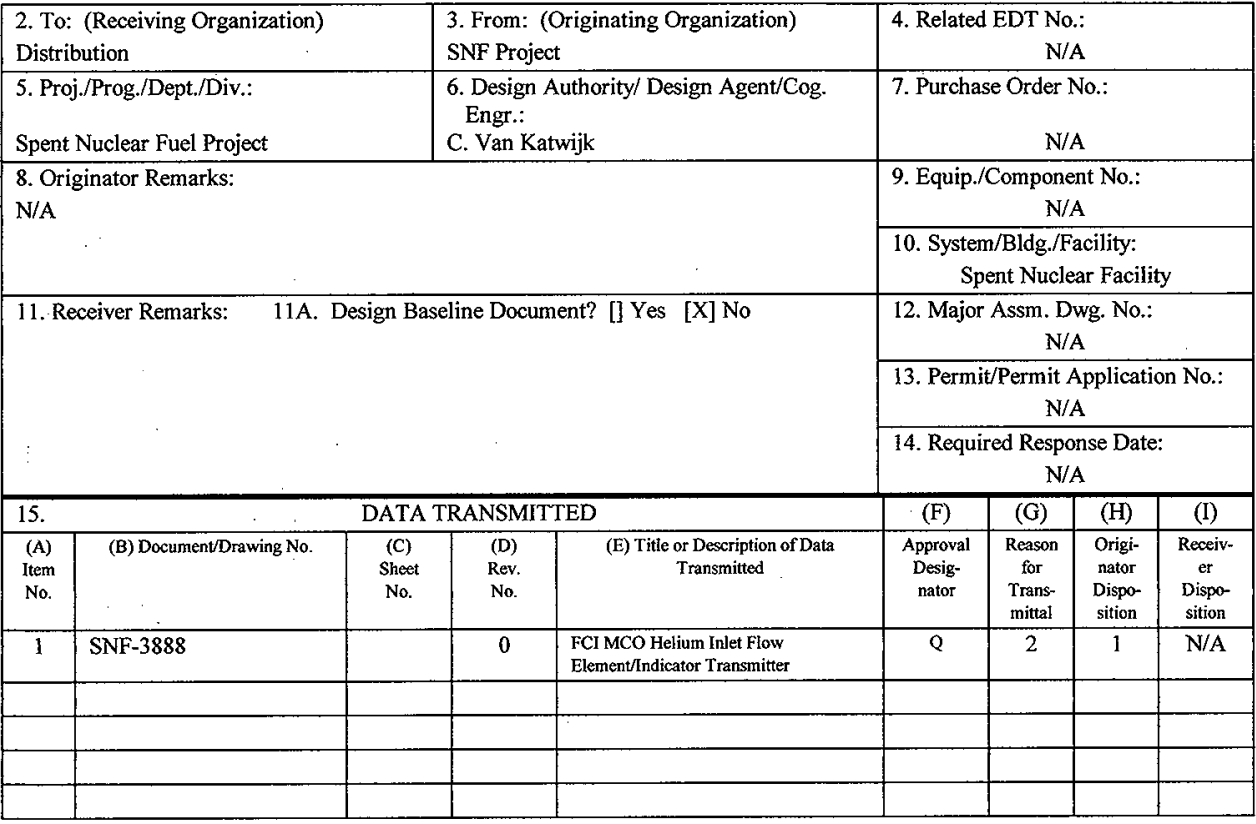

16.

KEY

\begin{tabular}{|l|ll|ll|}
\hline \multicolumn{1}{|c|}{ Approval Designator (F) } & \multicolumn{1}{|c|}{ Reason for Transmittal (G) } & \multicolumn{1}{c}{ Disposition (H) \& (I) } \\
\hline E, S, Q, D or N/A & 1. Approval & 4. Review & 1. Approved & 4. Reviewed no/comment \\
(see WHC-CM-3-5, & 2. Release & 5. Post-Review & 2. Approved w/comment & 5. Reviewed w/comment \\
Sec.12:7) & 3. Information & 6. Dist. (Receipt Acknow. Required) & 3. Disapproved w/comment & 6. Receipt acknowledged \\
\hline
\end{tabular}
17. SIGNATURE/DISTRIBUTION

(See Approval Designator for required signatures)

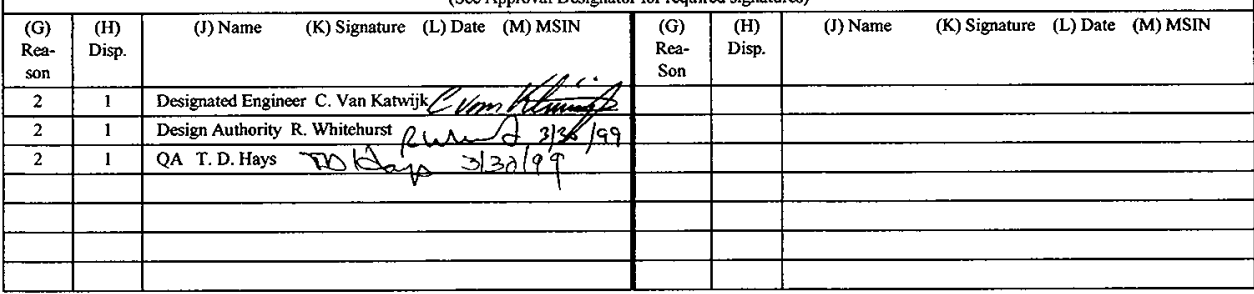

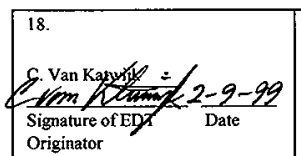
Originator
20. R.'Whitehurst

Design Authority! Cognizant Manager
21. DOE APPROVAL (if required)

Ctrl. No.

[] Approved

I] Approved w/comments

D Disapproved w/comments
Date

(1)

Engr.:

9. Equip./Component No.:

10. System/Bldg./Facility:

2. Major Assm. Dwg. No.:

13. Permit/Permit Application No.: sponse Date:
Authorized Representative Date for Receiving Organization

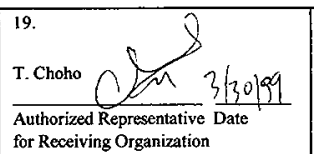


SNF-3888, Rev. 0

\section{FCI MCO Helium Inlet Element / Indicator Transmitter}

Carl Van Katwijk

Numatec Hanford Co, Richland, WA 99352

U.S. Department of Energy Contract DE-AC06-96RL13200

EDT/ECN: 626261

UC: 620

Org Code: $2 \mathrm{G} 300$

Charge Code: 105559/A000

B\&R Code: 39EW40400

Total Pages: 4

Key Words: Mass Flow Rate Meter / Indicator MCO

Abstract: FCI Helium Inlet Flow Element / Indicator Transmitter

CGI-SNF-D-13-P4-012

TRADEMARK DISCLAIMER. Reference herein to any specific commercial product, process, or service by trade name, trademark, manufacturer, or otherwise, does not necessarily constitute or imply its endorsement, recommendation, or favoring by the United States Govemment or any agency thereof or its contractors or subcontractors.

Printed in the United States of America. To obtain copies of this document, contact: Document ControlServices P.O Box 950 Mailstop H6-08, Richland WA 99352, Phone (509) 372-2420; Fax (509) 376-4989.

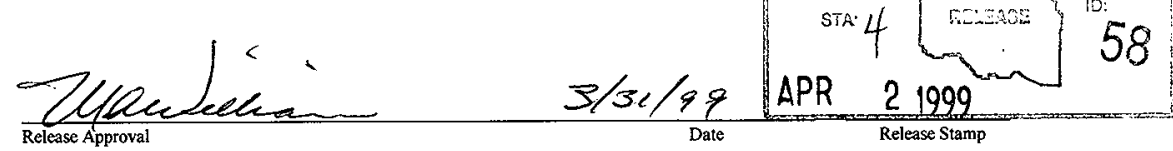


Commercial Grade Item Upgrade Dedication Form ECN No. NA CGINo. CGI-SNF-D-13-P4-012 Title: FCI MCO BELIUM INLET FLOW ELEMENT/ ONDICATOR TRANSMITTER

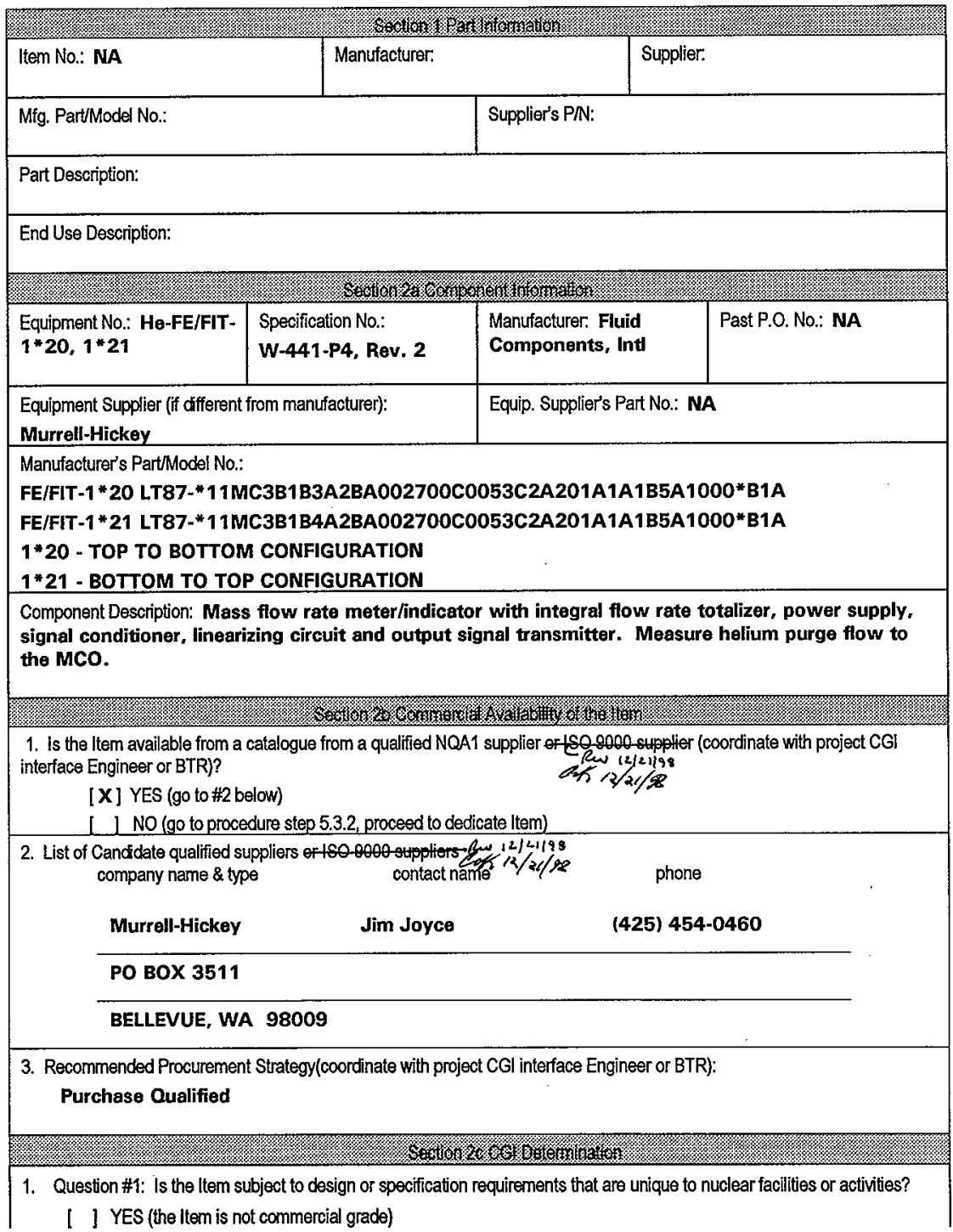




\section{1 ] NO (continue)}

2. Question \#2: Is the Item used in applications other than nuclear facilities or activities?

I I NO (the item is not commercial grade)

1 1 YES (continue)

3. Question \#3: Is the item ordered from manufacturer/supplier on the basis or specitications set forth in the manufacturers catalog?

[ ] NO (the ltem is not commercial grade)

1 ] YES (continue)

I I All three criteria have been satisfied. The ltem meets the definition of commercial grade.

[X] It is determined that the item is not commercial grade. The item is currently specified to be procured as safetygrade from a qualified vendor and no commercial dedication is required.

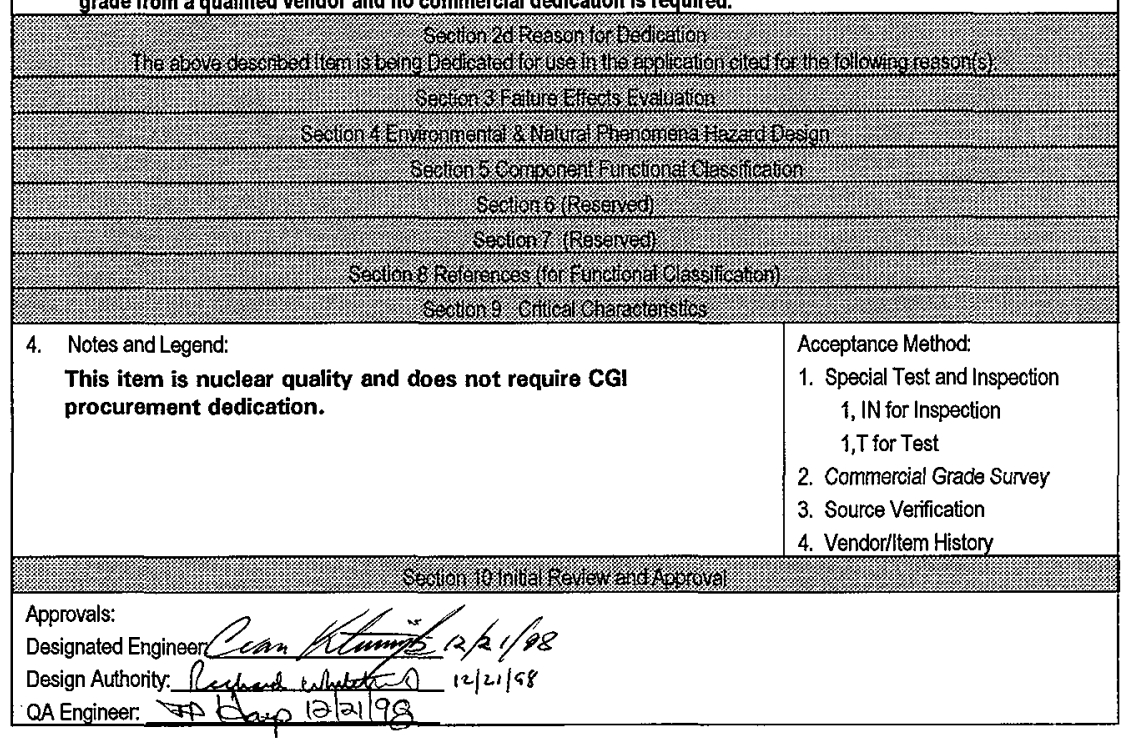




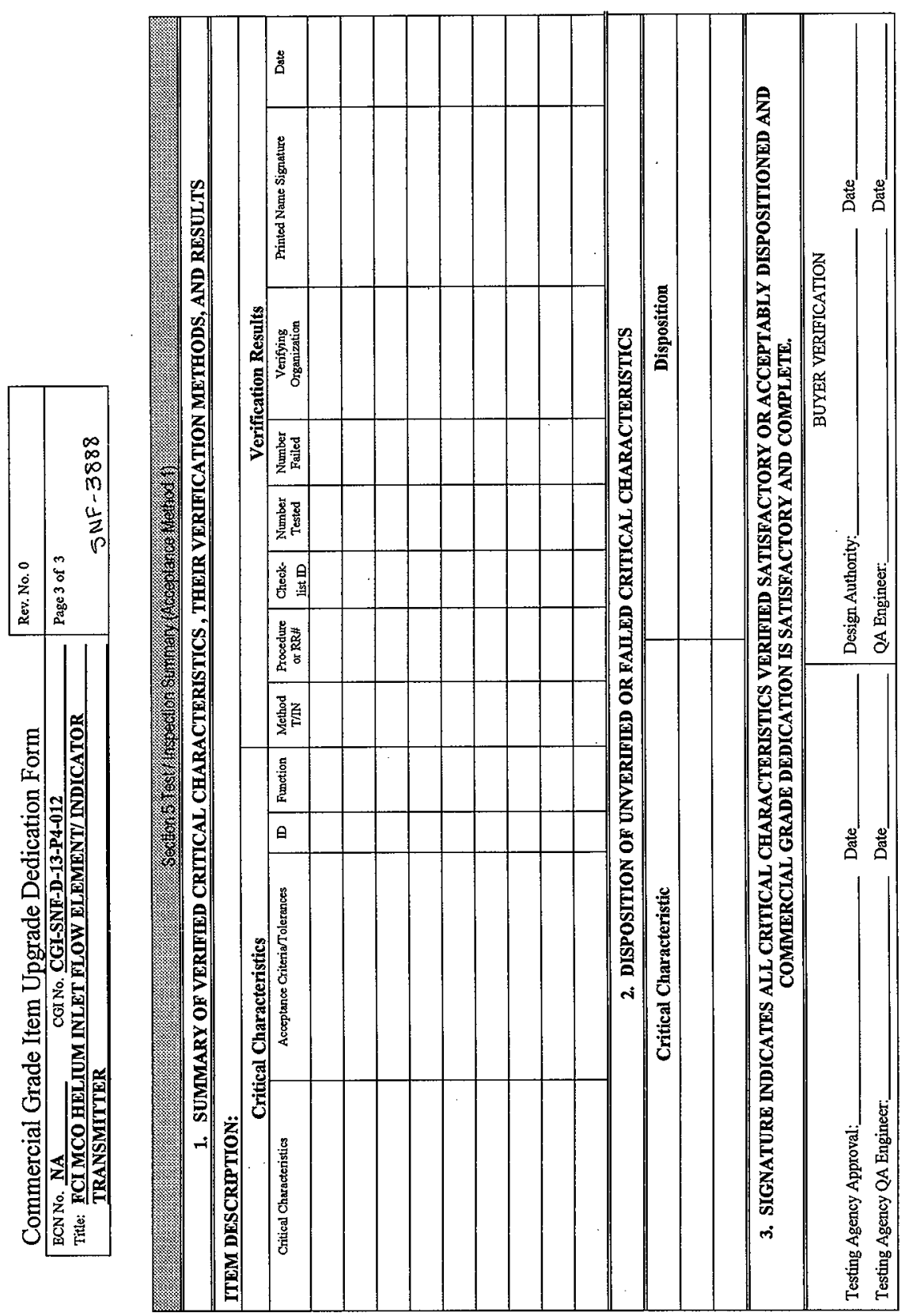

